\title{
Margaret McCartney: Our messy divorce from the EU
}

\author{
Margaret McCartney general practitioner
}

\section{Glasgow}

The United Kingdom has voted to leave the European Union. Now comes the messy, expensive divorce, with the pound in freefall. I am heartbroken. The need for a referendum was unclear. And the campaign was rotten from the start. It was full of misinformation, which failed to correct vital statistics and allowed the population to believe unchecked factual biases.

We are betrayed by false allure and the idea that the EU is to blame for everything bad in the UK. But there will be no extra village fêtes, bunting, or flat beer in Brexit. What does leaving mean for our NHS and research community? More borders. Less unity. More disruption. More duplication. More inefficiency.

A former commodity broker turned leader of the UK Independence Party, Nigel Farage, is the face of Brexit and a regular media guest. The NHS has been supported by immigrants for decades because it has consistently failed to attract and retain enough British staff. But, rather than welcoming and appreciating this, Farage has repeatedly demonised immigrants, failing to appreciate our reliance on these NHS workers, who also pay taxes.

There was a clear association between the vote and age. ${ }^{1}$

Younger people were more likely to want to stay in the EU and will have to live longer with the consequences of many older people's votes to leave. A generation is being (even more) disenfranchised. Young people now have to pay for university education and graduate with huge debts, unlike their elders. And they can't afford homes, because older generations creamed off council houses and because of astronomical house price rises. Intergenerational conflict is a major source of social instability, and there will be more.
The UK has rejected the principles of the EU-collectivism and peaceable cooperation. ${ }^{2}$ Climate change cannot be dealt with by one small island festering in self denial and obsessed with border control. Another Scottish independence vote is now inevitable. Sinn Féin is calling for a vote on a united Ireland. And several political leaders with extreme nationalist tendencies in other EU countries are calling for referendums for their countries. Coupled with a jealous fear of our neighbours, this self interest scares me.

The Leave campaign said that the UK pays the EU $£ 350 \mathrm{~m}$ ( $€ 438 \mathrm{~m} ; \$ 487 \mathrm{~m}$ ) a week and that this would be better spent on UK public services such as the NHS. ${ }^{3}$ Well, let's see it-every penny. (Farage already seems to have distanced himself from this. $^{4}$ )

In messy divorces, it's the lawyers who make a packet, while often the children are neglected. If you haven't met your elected representatives in a while, I suggest that now is a good time to make an appointment and hold the Leavers to account.

The Leave campaign said that $£ 350 \mathrm{~m}$ a week goes to the EU and would be better spent on services like the NHS. Well, let's see it—every penny

1 Kirk A, Dunford DEU. Referendum: how the results compare to Britain's educated, old, and immigrant population. Daily Telegraph 2016 Jun 24. www.telegraph.co.uk/news/2016 06/24/eu-referendum-how-the-results-compare-to-the-uks-educated-old-an/.

2 European Union. The founding principles of the union. http://europa.eu/scadplus/ constitution/objectives_en.htm.

3 Vote Leave Take Control. A vote to remain is the riskier option. www.voteleavetakecontrol. org/balance_sheet.

4 McCann K, Morgan T. Nigel Farage: $£ 350$ million pledge to fund the NHS was "mistake." Daily Telegraph 2016 Jun 24. www.telegraph.co.uk/news/2016/06/24/nigel-farage-350million-pledge-to-fund-the-nhs-was-a-mistake/.

Published by the BMJ Publishing Group Limited. For permission to use (where not already granted under a licence) please go to http://group.bmj.com/group/rights-licensing/ permissions 